\title{
Rheological Properties of Dough and Quality of Salted Noodles Supplemented with Djulis (Chenopodium formosanum Koidz.) Flour
}

\author{
Po-Hsien Li ${ }^{1}$, Wen-Chien $\mathrm{Lu}^{1}$, Chang-Wei Hsieh ${ }^{1}$, Tai-Chen $\mathrm{Li}^{1} \&$ Da-Wei Huang ${ }^{2}$ \\ ${ }^{1}$ Department of Medicinal Botanical and Health Applications, Da-Yeh University, Changhua, Taiwan \\ ${ }^{2}$ Department of Food \& Beverage Management, China University of Science and Technology, Taipei City, \\ Taiwan \\ Correspondence: Po-Hsien Li, Department of Medicinal Botanical and Health Applications, Da-Yeh University, \\ No.168, University Rd., Dacun, Changhua 51591, Taiwan. Tel: 886-4-851-1655 ext. 6233. E-mail: \\ pohsien0105@gmail.com
}

Received: March 11, 2015 Accepted: April 12, 2015 Online Published: May 15, 2015

doi:10.5539/jas.v7n6p84 URL: http://dx.doi.org/10.5539/jas.v7n6p84

\begin{abstract}
Djulis (Chenopodium formosanum Koidz.) has attracted attention worldwide for its nutritional value and health benefit. To examine the potential application of djulis flour in oriental starch-based staple products, we supplemented wheat flour with djulis flour in different proportions to investigate the rheological properties of dough and determine the sensory and textural profile of salted noodles. For dough characteristics measured by farinography and extensography, increased amount of djulis flour decreased the departure time, stability, arrival time and extensibility of dough, but increased the maximum resistance to extension. The cooking loss and hardness of salted noodles increased with increased amount of djulis flour. However, the overall sensory acceptability did not differ between salted noodles with djulis flour and controls $(p<0.05)$. In conclusion, djulis flour could be proportional incorporated into wheat flour and have a positive influence on salted noodle sensory quality.
\end{abstract}

Keywords: djulis, salted noodle, dough characteristics, sensory quality

\section{Introduction}

Djulis (Chenopodium formosanum Koidz.), belonging to the Chenopodium genus, is an annual crop plant traditionally used by the people worldwide. Djulis grains are edible, commonly served as fermented materials in the process of making liquor, and possess highly nutritional and functional components such as essential amino acids, dietary fiber, betanin, daidzein and genistein (Tsai et al., 2010; Lutz et al., 2013). The well-recognized nutritive value allowed this genus plant to be included in the NASA list of candidate crops for life support in outer space (Schlick \& Bubenheim, 1996).

Djulis contains a natural antioxidant betanin and has shown ferric reducing ability of plasma and DPPH scavenging capacity (Tsai et al., 2010). Feeding animals with djulis grain nanoparticles reduced plasma low-density lipoprotein cholesterol and total cholesterol levels (Tsai et al., 2011). This crop plant has ethnobotany value; however, the application of the crop to food has received little study.

There is a new tendency to incorporate high-volume fractions of plant materials to the basic ingredients of wheat flour (De Oliveira et al., 2006; Koh et al., 2011; Li et al., 2012; Choy et al., 2013). Such incorporated ingredients can provide different flavors, colors, additional nutrients and, often, health benefits. However, these incorporations have significant effects on the physicochemical properties of the dough (Silva et al., 2013) and sensory properties of products (Han et al., 2013). The addition of legume flours to durum wheat flour causes deteriorated cooking quality and textural properties of these products (Petitot et al., 2010). Noodles prepared with $20 \%$ buckwheat flour showed increased antioxidant rutin content and enhanced quality of instant noodles (Choy et al., 2013). Salted noodles based on blends of wheat flour and 5\% to $15 \%$ purple yam flour show increased water adsorption and decreased dough stability on farinography, and the purple yam enrichment conferred redness to the salted noodles as a pleasant purple-red color for consumers ( $\mathrm{Li}$ et al., 2012).

Noodle products are the wheat flour-based staple food in many parts of Asia; they have been consumed for thousands of years. Traditional salted noodles are made from common ingredients (wheat flour, water and salt), 
and although claimed to be rich in carbohydrate, they lacks other essential nutritional components, which are removed during wheat flour refinement (Choo \& Azin, 2010). Nowadays, foods with high nutritional value and functional properties of supplements are popular. In this study, we aimed to investigate the physical and sensory properties of salted noodles with wheat flour partly superseded by djulis flour. The rheological properties of dough with wheat flour and djulis flour blends were investigated by farinography and extensography.

\section{Materials and Methods}

\subsection{Wheat Flour}

Wheat flour was provided by Chi-Fa Enterprise Co. (Taichung, Taiwan), which was composed of hard red spring wheat and hard red winter wheat in a 2:3 ratio. The moisture, crude protein, and ash content of wheat flour were $13.52 \%, 11.74 \%$, and $0.35 \%$, respectively.

\subsection{Djulis Flour}

Djulis (Chenopodium formosanum Koidz.) (Figure 1) was cultivated on November 2013 at a local farm (Pingtung, Taiwan). Djulis grains were separated, sieved, washed and then dried by a vacuum-freeze drier. The dried djulis grains were blended by use of a domestic blender and passed through a 100-mesh $(150 \mu \mathrm{m})$ sieve. The djulis flour was collected and stored in a freezer with a double-bagged polyethylene. The moisture, crude protein, and ash content of djulis flour were $9.45 \%, 8.43 \%$, and $0.25 \%$, respectively.

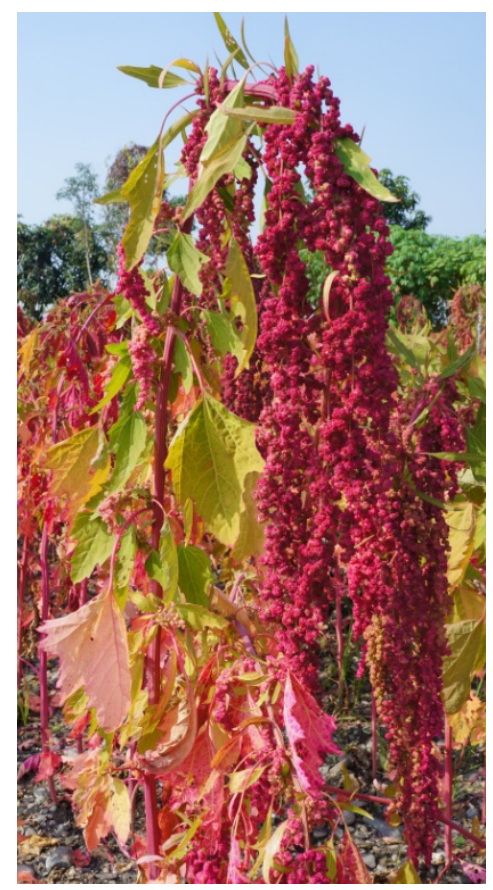

Figure 1. Appearance of djulis (Chenopodium formosanum Koidz.)

\subsection{Preparation of Blended Samples}

Djulis flour were blended individually with wheat flour at ratios of $0 / 100$ (djulis flour/wheat flour), 5/95, 10/90, $15 / 85$, and 20/80. Mixing was on a weight (w/w) basis, as described by Zaidul et al. (2007).

\subsection{Dough Characteristics}

The rheological characteristics of dough prepared from control wheat flour and mixtures of wheat flour and djulis flour were determined by farinograph (E-380, Brabender OHG, Germany) according to AACC (2000) standard method. Dough strength was evaluated in terms of farinograph water absorption, dough development time, departure time, dough stability, arrival time and mixing tolerance index were recorded manually. The thermostate of the farinograph was adjusted to maintain the temperature at $30^{\circ} \mathrm{C}$.

For extension tests dough was prepared using the farniograph. The extension tests were conducted in accordance with the standard procedure, using the extensograph (Brabender OHG, Germany). The following indices were determined: extensibility and resistance to extension. Measurements of the above farinograph and extensograph 
indices were made in four replications.

\subsection{Preparation of Salted Noodles}

Salted noodles were prepared as previously described (Li et al., 2012) and with modification. The wheat flour was supplemented with different proportions of djulis flour and blended thoroughly, and then $300 \mathrm{~g}$ of each mixture was mixed $102 \mathrm{~mL}$ of distilled water $\left(25^{\circ} \mathrm{C}\right)$ containing $6 \mathrm{~g}$ of salt at $10 \mathrm{rpm}$ for $8 \mathrm{~min}$ to form dough. Dough was passed through the rollers of a noodle machine (Ohtake Noodle Machine Mfg. Co., Tokyo, Japan) at $8 \mathrm{rpm}$ and a $3 \mathrm{~mm}$ gap. Folding and sheeting were repeated twice more. The dough sheet was allowed to rest for $30 \mathrm{~min}$, and then was put through the sheeting rolls 3 times at progressively decreasing roll gaps of $2.60,2.33$, and $2.00 \mathrm{~mm}$, and then, the dough sheets were cut into noodle strips of $3 \mathrm{~mm}$ in width. Finally, the noodle strips were cut in lengths of $20 \mathrm{~cm}$ and air dried at room temperature. Dried noodles were stored in sealed polyethylene bags for further measurements.

\subsection{Optimal Cooking Time}

The optimal cooking time for each sample was determined by using the AACC Method 66-50 (AACC, 2000). It was evaluated by observing the time of disappearance of the white core of the noodle strands during cooking (every $15 \mathrm{~s}$ ), by squeezing the noodle strands between 2 transparent glass slides.

\subsection{Water Absorption}

Dry noodles $(10 \mathrm{~g})$ were boiled in $300 \mathrm{~mL}$ boiling water until the white core inside the noodles disappeared, placed in cool water for $5 \mathrm{~min}$, then placed on filter paper for $5 \mathrm{~min}$ to remove excess water. Water absorption of the noodles was calculated by the following equation:

$$
\text { Water absorption }(\%)=\frac{M_{1}-M_{2} \times(1-W)}{M_{2} \times(1-W)} \times 100
$$

Where, $M_{l}$ is the weight of noodles after cooking $(\mathrm{g}) ; M_{2}$ is the weight of noodles before cooking $(\mathrm{g})$; and $W$ is the moisture content of noodles before cooking (\%).

\subsection{Cooking Loss}

Cooking loss was measured according to the AACC Method 66-50 (AACC, 2000). Cooking water was evaporated and dried at $105{ }^{\circ} \mathrm{C}$ to a constant weight. Cooking loss was expressed as a percentage of dry matter lost during cooking to dry sample weight.

$$
\text { Cooking loss }(\%)=\frac{M}{G \times(1-W)} \times 100
$$

Where, $M$ is the weight of dry matter (g); $G$ is the weight of noodles before cooking; and $W$ is the moisture content of noodles before cooking (\%).

\subsection{Color Measurements}

The color of the salted noodles with different proportions of djulis flour was measured with use of a colorimeter (SE2000, Nippon Denshoku Co., Japan) equipped with D65 illuminant, using the CIE $1976 L^{*}, a^{*}$ and $b^{*}$ color scale. $L^{*}$ was a measurement of brightness $(0-100), a^{*}$ represents the red-green coordinates while $b^{*}$ measures the blue-yellow coordinates of a product. A piece of the cooked noodle sheets was placed in the sample holder and the surface color was measured at 3 different positions.

\subsection{Texture Profile Analysis}

The hardness, cohesiveness, springiness, gumminess, and chewiness of the cooked salted noodles were tested by the texture profile analysis (TPA) with a texture analyzer (TA-XT2, Stable Micro Systems, UK). Dry noodles were cooked in $500 \mathrm{~mL}$ boiling distilled water for $5 \mathrm{~min}$ then rinsed with cold water for 1 min immediately. Nine replicates of noodles were evaluated within 5 min after cooling. The noodles were placed on a flat metal plate and compressed twice to $70 \%$ of their original thickness, using a 3-mm-diameter steel cylinder probe at $2 \mathrm{~mm} / \mathrm{s}$.

\subsection{Sensory Evaluation}

Ten panelists were selected from college students at the Department of Medicinal Botanicals and Health Applications in Da-Yeh University. The panelists were trained five times for $2 \mathrm{~h}$ each time according to the Texture Profile Analysis training produced by Civille and Szczesniak (1973). A multi-sample comparison test was used to evaluate color, firmness, smoothness, stickiness, flavor and overall acceptability of the cooked noodles. The samples were evaluated on a 9-point hedonic scale from 1 (extremely dislike) to 9 (extremely like). The salted noodles were cooked in boiling distilled water for the optimal time and then cooled in tap water for 30 
$\mathrm{s}$ before serving. Samples were presented individually in a randomized order to panelists on uniform plastic dishes. Panelists rinsed their mouths with purified water between samples.

\subsection{Scanning Electron Microscopy (SEM) of Salted Noodles}

Salted noodles underwent SEM (Model ABT-150S, Topon Corp., Japan). Samples were sprinkled on double-sided adhesive tape fixed on an aluminum stub. The sample was coated with a gold-palladium (Model JBS-ES 150, Ion sputter coater, Topon Corp., Japan). An accelerating potential of $15 \mathrm{kV}$ was used during SEM in this study.

\subsection{Statistical Analysis}

Data are described with mean \pm SD and were analyzed using SAS software (1996 ver. SAS Inst. Inc., Cary, NC) by the generalized linear model procedure. The Duncan's new multiple range tests was used to compare the differences among means. Significance was defined at $\mathrm{P}<0.05$.

\section{Results and Discussion}

\subsection{Farinograph Characteristics}

The farinograph variables for djulis flour and wheat flour blends are in Table 1. Dough quality was significantly affected by the addition of djulis flour. Water absorption increased significantly with increasing content from 0 to $20 \%$. This tendency was expected due to the hydroxyl groups in the dietary fiber and starch structure of djulis flour, which allows more water interactions through hydrogen bonding (Roseell et al., 2001).

Table 1. Farinographic analysis of wheat dough containing different proportions of djulis flour

\begin{tabular}{lllllll}
\hline & \multicolumn{5}{c}{ Farinographic dough characteristics } \\
\cline { 2 - 7 } Djulis flour (\%) & $\begin{array}{l}\text { Water absorption } \\
(\%)\end{array}$ & $\begin{array}{l}\text { Dough development } \\
\text { time (min) }\end{array}$ & $\begin{array}{l}\text { Departure time } \\
(\text { min) }\end{array}$ & $\begin{array}{l}\text { Stability } \\
(\mathrm{min})\end{array}$ & $\begin{array}{l}\text { Arrival time } \\
(\mathrm{min})\end{array}$ & $\begin{array}{l}\text { Mixing tolerance } \\
\text { index (B.U.) }\end{array}$ \\
\hline 0 & $64.7^{\mathrm{d}} \pm 0.4$ & $1.7^{\mathrm{c}} \pm 0.4$ & $24.4^{\mathrm{a}} \pm 0.2$ & $22.4^{\mathrm{a}} \pm 0.7$ & $12.3^{\mathrm{a}} \pm 0.5$ & $19.3^{\mathrm{c}} \pm 1.4$ \\
5 & $65.8^{\mathrm{c}} \pm 0.3$ & $2.6^{\mathrm{b}} \pm 0.1$ & $17.4^{\mathrm{b}} \pm 0.2$ & $15.3^{\mathrm{b}} \pm 0.1$ & $8.6^{\mathrm{b}} \pm 0.4$ & $59.1^{\mathrm{d}} \pm 3.7$ \\
10 & $65.9^{\mathrm{bc} \pm 0.7}$ & $2.5^{\mathrm{b}} \pm 0.1$ & $16.2^{\mathrm{c}} \pm 0.4$ & $13.5^{\mathrm{c}} \pm 0.5$ & $7.1^{\mathrm{b}^{\mathrm{b}} \pm 0.1}$ & $82.4^{\mathrm{c}} \pm 2.3$ \\
15 & $66.7^{\mathrm{b}} \pm 0.3$ & $2.7^{\mathrm{ab}} \pm 0.2$ & $13.7^{\mathrm{d}} \pm 0.1$ & $10.6^{\mathrm{d}} \pm 0.1$ & $5.4^{\mathrm{c}^{\mathrm{c}} \pm 0.2}$ & $104.1^{\mathrm{b}} \pm 3.6$ \\
20 & $67.4^{\mathrm{a}} \pm 0.2$ & $2.9^{\mathrm{a}} \pm 0.1$ & $12.5^{\mathrm{c}} \pm 0.6$ & $8.7^{\mathrm{d}} \pm 0.6$ & $4.2^{\mathrm{d}} \pm 0.2$ & $123.4^{\mathrm{a}} \pm 5.8$ \\
\hline
\end{tabular}

Note. ${ }^{\text {a-e }}$ different letters within the same column differed significantly $(\mathrm{p}<0.05)(\mathrm{n}=5)$.

Dough development time is the time from the addition of water to the flour until the dough reaches the greatest torque. For control ( $0 \%$ djulis flour) and wheat flour blends with $5 \%$ to $20 \%$ djulis flour, dough development time changed with the addition of djulis flour. The dough development time, departure time, stability and arrival time values are indicators of dough strength, and high values suggest strong dough ( $\mathrm{Li}$ et al., 2012). Zaidul et al. (2004) proposed that dough development time was related to water absorption percentage of the flours. An increase in water absorption will often increase dough development time. We found that the dough departure time decreased with increasing djulis flour proportion from $5 \%$ to $20 \%$.

Dough stability is defined as the difference in time when the top of the curve first intercepts and then leaves the 500 B.U. line on farinography. In general, this value gives some indication of protein weakening and dough strength (Heo et al., 2013). Control wheat flour showed the highest dough stability, but increasing the proportion of djulis flour decreased the dough stability. Strong gluten of wheat flour gave the highest stability value in control, but the stability was influenced in the flour blends at all ratios. Our study agreed with findings from Amudha et al. (2002), who showed that water absorption slightly increased and dough stability decreased with increasing amount of soya flour.

The mixing tolerance index indicated a consistency difference in dough between the height at the peak and the height 5 min later. The mixing tolerance index of the dough significantly increased with increasing proportion of djulis flour added. The dilution of gluten in the formulated flour decreased the interaction between starch and gluten and resulted in the higher mixing tolerance index (Chen et al., 1988).

\subsection{Extensograph Measurements}

The effect of various ratios of djulis flour on the extensographic extensibility after 45, 90, 135 min resting time 
are shown in Table 2. The addition of djulis flour with increasing proportions from $5 \%$ to $20 \%$ decreased the extensibility of dough. The substitution of wheat flour with djulis flour resulted in decreased gluten, so the binding structure of dough became weak. The resistance to extension increased between the fermentation stages, with the greatest increase between 45 and $90 \mathrm{~min}$. The resistance decreased with increased proportion of djulis flour added from $5 \%$ to $20 \%$. The substitution of wheat flour by djulis flour resulted in the decrease of gluten; thus, the binding structure of dough became weak. Our results agree with Li et al. (2012), who incorporated purple yam flour to enrich dough and decreased the extensographic extensibility values of the dough with increasing purple yam flour proportions.

Table 2. Extensigraphic properties of wheat dough containing different proportions of djulis flour with different resting times

\begin{tabular}{|c|c|c|c|c|c|c|}
\hline \multirow{3}{*}{ Djulis flour (\%) } & \multicolumn{6}{|c|}{ Extensigraphic properties } \\
\hline & \multicolumn{3}{|c|}{ Maximum resistance to extension (B.U.) } & \multicolumn{3}{|c|}{ Extensibility $(\mathrm{cm})$} \\
\hline & $45(\min )$ & $90(\mathrm{~min})$ & 135 (min) & $45(\min )$ & $90(\mathrm{~min})$ & $135(\mathrm{~min})$ \\
\hline 0 & $592^{\mathrm{d}}$ & $727^{d}$ & $729^{\mathrm{e}}$ & $17.1^{\mathrm{a}}$ & $12.9^{\mathrm{a}}$ & $14.1^{\mathrm{a}}$ \\
\hline 5 & $672^{\mathrm{c}}$ & $791^{\mathrm{c}}$ & $788^{\mathrm{d}}$ & $13.7^{\mathrm{b}}$ & $12.6^{\mathrm{a}}$ & $13.6^{\mathrm{b}}$ \\
\hline 10 & $701^{\mathrm{c}}$ & $912^{\mathrm{b}}$ & $853^{\mathrm{c}}$ & $13.6^{\mathrm{b}}$ & $11.9^{\mathrm{b}}$ & $10.5^{\mathrm{c}}$ \\
\hline 15 & $795^{\mathrm{b}}$ & $920^{\mathrm{b}}$ & $972^{\mathrm{b}}$ & $12.5^{\mathrm{c}}$ & $10.4^{\mathrm{c}}$ & $10.4^{\mathrm{c}}$ \\
\hline 20 & $882^{\mathrm{a}}$ & $957^{\mathrm{a}}$ & $>1000^{\mathrm{a}}$ & $11.7^{\mathrm{d}}$ & $9.9^{\mathrm{c}}$ & $9.1^{\mathrm{d}}$ \\
\hline
\end{tabular}

Note. ${ }^{\text {a-e }}$ different letters within the same column differed significantly $(\mathrm{p}<0.05)(\mathrm{n}=5)$.

\subsection{Cooking Quality of Noodle}

Cooking quality is an important parameter in determining the acceptability of noodles by consumers (Chillo et al., 2008). Noodles with good quality are firm and elastic and have lowing cooking losses and good surface conditions (Gianibelli et al., 2005; Tan et al., 2009). The optimal cooking time, water absorption and cooking loss of djulis-enhanced noodles are in Table 3. As compared with noodles made with only wheat flour, increasing proportions of djulis flour decreased the optimal cooking time of the noodles, from $4.75 \mathrm{~min}$ to $3.50 \mathrm{~min}$. These findings are consistent with Manthey et al. (2004) and Choy et al. (2013), who added 30\% buckwheat bran flour and $40 \%$ common buckwheat flour and lowered the optimal cooking time of spaghetti and instant noodles. This finding may be due to physical disruption of the gluten matrix and low overall density of the product.

Water absorption is an indication of the quantity of water absorbed by the noodles during cooking, an important characteristic in determining the cooking quality of noodles (Chung et al., 2012). Insufficient water absorption could result in noodles with a hard and coarse texture, but excess water absorption usually produces very soft and sticky noodles. Noodles with $5 \%$ to $20 \%$ djulis flour showed significantly lower water uptake as compared with the control (Table 3). This result is consistent with the report of Chillo et al. (2008).

Cooking loss is defined as the amount of solids that dissolve in water during cooking and may be an indicator of noodle structural integrity during cooking (Liu et al., 2012). The control sample showed less cooking loss than with different proportions of djulis flour (Table 3). These observations correspond with the water absorption results, with decreasing trend shown. Wheat flour can establish a gluten matrix, which provides the structure of the noodle. However, the addition of djulis flour (non-gluten) may have weakened the gluten strength and interrupted the overall structure of the noodles. This finding explains the increased leaching of solids from the noodles into the cooking water with increased djulis flour proportions. 
Table 3. Qualities of salted noodles with different proportions of djulis flour

\begin{tabular}{llllll}
\hline \multirow{2}{*}{ Parameters } & \multicolumn{5}{c}{ Djulis flour proportion (\%) } \\
\cline { 2 - 6 } & 0 & 5 & 10 & 15 & 20 \\
\hline Optimal cooking time (min) & $4.75^{\mathrm{a}}$ & $4.50^{\mathrm{a}}$ & $4.00^{\mathrm{b}}$ & $3.50^{\mathrm{c}}$ & $3.50^{\mathrm{c}}$ \\
Water absorption $(\mathrm{g} / 100$ g noodles) & $149.7^{\mathrm{a}}$ & $144.8^{\mathrm{b}}$ & $141.2^{\mathrm{b}}$ & $136.2^{\mathrm{c}}$ & $126.1^{\mathrm{d}}$ \\
Cooking loss $(\mathrm{g} / 100$ g noodles, dry basis $)$ & $7.3^{\mathrm{d}}$ & $7.7^{\mathrm{c}}$ & $8.2^{\mathrm{bc}}$ & $8.7^{\mathrm{b}}$ & $9.4^{\mathrm{a}}$ \\
Lightness $\left(L^{*}\right)$ & $64.1^{\mathrm{a}}$ & $55.2^{\mathrm{b}}$ & $48.3^{\mathrm{c}}$ & $46.7^{\mathrm{c}}$ & $43.1^{\mathrm{c}}$ \\
Red-green $\left(a^{*}\right)$ & $0.23^{\mathrm{d}}$ & $4.21^{\mathrm{c}}$ & $5.37^{\mathrm{b}}$ & $5.65^{\mathrm{b}}$ & $6.93^{\mathrm{a}}$ \\
Yellow-blue $\left(b^{*}\right)$ & $12.45^{\mathrm{c}}$ & $11.92^{\mathrm{b}}$ & $12.93^{\mathrm{ab}}$ & $13.12^{\mathrm{ab}}$ & $13.61^{\mathrm{a}}$ \\
Hardness $(\mathrm{kg})$ & $1.27^{\mathrm{e}}$ & $1.94^{\mathrm{d}}$ & $2.31^{\mathrm{c}}$ & $2.68^{\mathrm{b}}$ & $3.12^{\mathrm{a}}$ \\
Cohesiveness & $0.27^{\mathrm{a}}$ & $0.29^{\mathrm{a}}$ & $0.32^{\mathrm{a}}$ & $0.31^{\mathrm{a}}$ & $0.36^{\mathrm{a}}$ \\
Springiness & $0.82^{\mathrm{a}}$ & $0.78^{\mathrm{a}}$ & $0.74^{\mathrm{a}}$ & $0.76^{\mathrm{a}}$ & $0.84^{\mathrm{a}}$ \\
Guminess $(\mathrm{kg})$ & $0.42^{\mathrm{c}}$ & $0.67^{\mathrm{b}}$ & $0.73^{\mathrm{b}}$ & $0.77^{\mathrm{b}}$ & $0.92^{\mathrm{a}}$ \\
Chewiness & $0.38^{\mathrm{c}}$ & $0.65^{\mathrm{b}}$ & $0.74^{\mathrm{b}}$ & $0.72^{\mathrm{b}}$ & $0.98^{\mathrm{a}}$ \\
\hline
\end{tabular}

Note. ${ }^{\mathrm{a}-\mathrm{e}}$ different letters within the same row differed significantly $(\mathrm{p}<0.05)(\mathrm{n}=5)$.

\subsection{Color Measurements}

Color plays an important role in consumer acceptance of noodle products. The addition of djulis flour had an observable influence on the color of salted noodles (Table 3$)$. Compared to the control $(0 \%)$, the addition of djulis flor significantly decreased the value of $L^{*}$ and increased the value of $a^{*}$. This result indicates that the color of salted noodles formulated with djulis flour appeared to have a fairly uniform tinge of red color.

The yellow-blue $b^{*}$ values of salted noodles slightly increased with increasing proportion of djulis flour and turned to a yellowish color. Similar findings were reported by Rayas-Duarte et al. (1996), where the $L^{*}$ values for spaghetti containing buckwheat flour decreased significantly as compared with control samples.

\subsection{Texture Profile Analyses}

The texture profiles (hardness, cohesiveness, springiness, guminess and chewiness) of salted noodles were affected by the composition of the flour blend (Table 3). The increasing proportion of djulis flour increased the hardness of salted noodles from 1.27 to $3.12 \mathrm{~kg}$ of force, the cohesiveness and springiness of the salted noodles did not find significant changes. The hardness of salted noodles showed the same tendency as dough development time and dough mixing tolerance index with increasing proportion of djulis flour added to dough. Salted noodles with blended flour, substituting by djulis flour above 15\%, appeared significantly higher guminess and chewiness than control sample. These results agree with the findings of Amudha et al. (2002), who reported that the force required to compressing the product increased in direct proportion to the soya flour in the dough. In general, a partial and complete substitution of wheat flour with other materials can result in a negative correlation of noodle and pasta product firmness and chewiness, as was reported for superfine green tea powder (Li et al., 2012), purple yam flour (Li et al., 2012), wheat bran (Song et al., 2013) and common buckwheat flour (Choy et al., 2013), which agrees with our findings.

\subsection{Sensory Evaluation}

Figure 2 represents the sensory analyses of color, firmness, smoothness, stickness, flavor and overall acceptability of the cooked sample of noodles. Salted noodles with blended flour, with djulis flour $>15 \%$, appeared to have higher color, firmness, stickiness and flavor than control samples. However, smoothness did not differ among the five samples. The salted noodles containing $10 \%$ to $15 \%$ djulis flour had the same overall acceptability scores as the controls. Thus, substituting djulis flour for wheat flour up to $15 \%$ could obtain the similar quality and pleasant appearance as regular salted noodles.

\subsection{Observation of Noodle Microstructure}

The microstructure of dry salted noodles was observed by SEM (Figure 3). Cross-sectional surfaces of dried noodles were heavily covered by non-uniform amorphous gluten protein. The starch granules were imbedded deeply in the gluten network (Figure 3A). The oval shaped structures with diameters varying from 5 to $10 \mu \mathrm{m}$ 
that stick to one another might be the starch granules of wheat flour. The starch granules of djulis flour appeared polygonal, with diameters varying from 0.5 to $1 \mu \mathrm{m}$. The micro-morphology of cross-section of control and samples treated with $15 \%$ djulis flour differed. The surface structural feature seems to disrupt the gluten matrix and cause voids and holes for the starch to "fill up". The spaces were occupied by polygonal starch for samples with increased djulis proportion (Figure 3B).

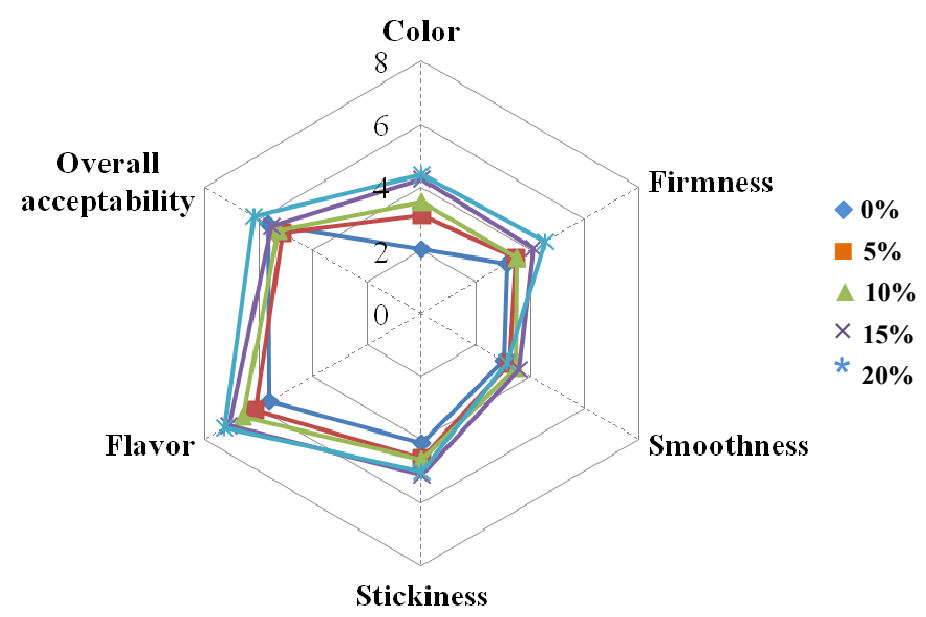

Figure 2. Effect of different proportions of djulis flour added to wheat flour on sensory analyses
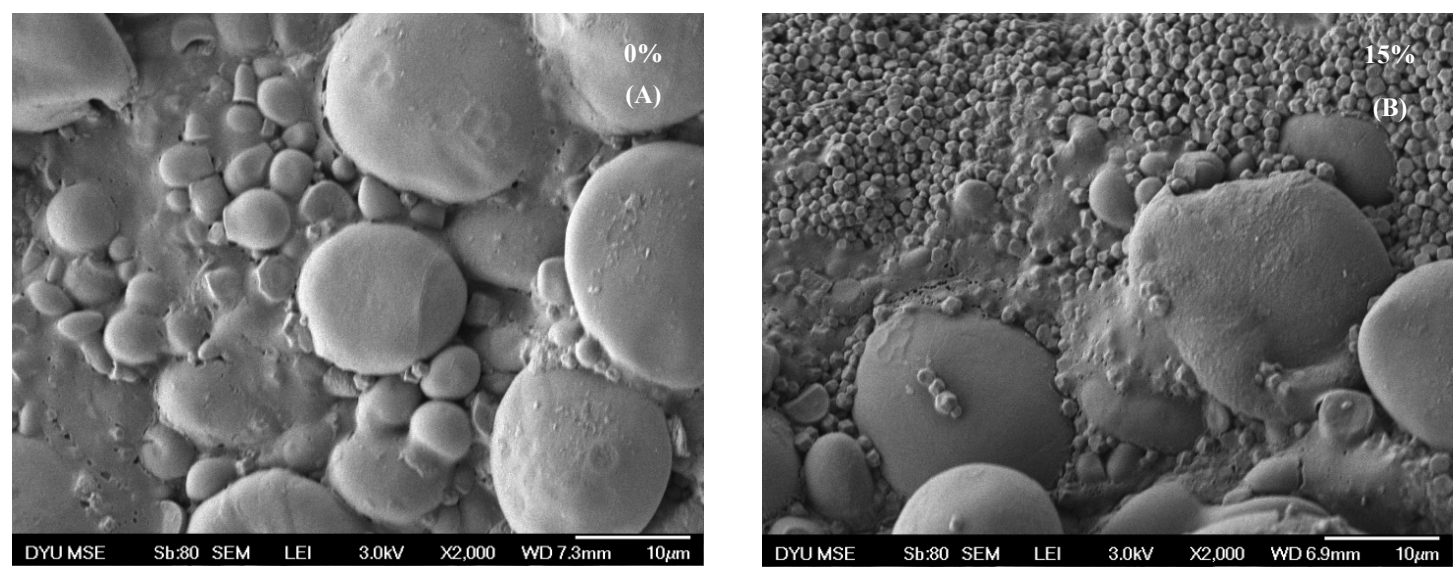

Figure 3. Scanning electron micrography of dry salted noodles (A) and that with $15 \%$ djulis flour (B)

\section{Conclusions}

It is possible to produce noodles of acceptable color and texture from wheat flour containing up to the least $15 \%$ djulis flour. In general, additions of djulsi flour will results in noodles with red color but still acceptable color at a $15 \%$ blend. With increasing proportion of djulis flour, salted noodle processing, handling and cooking characteristics deteriorated proportionally, primarily because of the gluten fraction, which was diluted with the added djulis flour. Supplementing salted noodles with $5 \%$ to $15 \%(\mathrm{w} / \mathrm{w})$ djulis flour had equal sensory properties as control samples in overall acceptability of noodles. Because djulis can benefit human health, this study may provide a scientific basis for the use of djulis flour in functional, starch-based staple foods.

\section{Acknowledgements}

This study was made possible through financial support provided by the Basic Research Priorities Program of Da-Yeh University (grant no. ORD102036).

\section{References}

American Association of Cereal Chemists. (2000). Approved methods of the American Association of Cereal 
Chemists (10th ed.). St. Paul Minnestoa, U.S.A.

Association of Official Analytical Chemists. (1990). Official methods of analysis (15th ed.). Washington, DC, U.S.A.

Amudha, S., Ravi, R., Bhat, K. K., \& Seethalakshmi, M. K. (2002). Studies on the quality of fried snacks based on blends of wheat flour and soya flour. Food Quality and Preference, 13(5), 267-273. http://dx.doi.org/10.1016/S0950-3293(02)00023-X

Chen, H., Rubenthaler, G. L., \& Schanus, E. G. (1988). Effect of apple fiber and cellulose on physical properties of wheat flour. Journal of Food Science, $304-305$. http://dx.doi.org/10.1111/j.1365-2621.1988.tb10242.x

Chillo, S., Laverse, J., Falcone, P. M., Protopapa, A., \& Del Nobile, M. A. (2008). Influence of the addition of buckwheat flour and durum wheat bran on spaghetti quality. Journal of Cereal Science, 47(2), 144-152. http://dx.doi.org/10.1016/j.jcs.2007.03.004

Choo, C. L., \& Aziz, N. A. A. (2010). Effects of banana flour and $\beta$-glucan on the nutritional and sensory evaluation of noodles. Food Chemistry, 119(1), 34-40. http://dx.doi.org/10.1016/j.foodchem.2009.05.004

Chung, H. J., Cho, A., \& Lim, S. T. (2012). Effect of heat-mositure treatment for utilization of germinated brown rice in wheat noodle. LWT Food Science and Technology, 47(2), 342-347. http://dx.doi.org/10.1016/j.lwt.2012.01.029

Choy, A. L., Morrison, P. D., Hughes, J. G., Marriott, P. J., \& Small, D. M. (2013). Quality and antioxidant properties of instant noodles enhanced with common buckwheat flour. Journal of Cereal Science, 57(3), 281-287. http://dx.doi.org/10.1016/j.jcs.2012.11.007

De Oliveira, M. K. S., Martinez-Flores, H. E., De Andrade, J. S., Garnica-Romo, M. G., \& Chang, Y. K. (2006). Use of pejibaye flour (Bactris gasipaes Kunth) in the production of food pastas. International Journal of Food Science and Technology, 41, 933-937. http://dx.doi.org/10.1111/j.1365-2621.2005.01145.x

Gianibelli, M. C., Sissons, M. J., \& Batey, I. L. (2005). Effect of source and proportion of waxy starches on pasta cooking quality. Cereal Chemistry, 82(3), 321-327. http://dx.doi.org/10.1094/CC-82-0321

Han, L., Zhou, Y., Tatsumi, E., Shen, Q., Cheng, Y., \& Li, L. (2013). Thermomechanical properties of dough and quality of noodles made from wheat flour supplemented with different grades of tartary buckwheat (Fagopyrum tataricum Gaertn.) flour. Food and Bioprocess Technology, 6(8), 1953-1962. http://dx.doi.org/10.1007/s11947-012-0831-8

Heo, S., Lee, S. M., Bae, I. Y., Park, H. G., Lee, H. G., \& Lee, S. (2013). Effect of lentinus edodes $\beta$-glucan-enriched materials on the textural, rheological, and oil-resisting properties of instant fried noodles. Food and Bioprocess Technology, 6(2), 553-560. http://dx.doi.org/10.1007/s11947-011-0735-z

Koh, L., Jiang, B., Kasapis, S., \& Foo, C. W. (2011). Structure, sensory and nutritional aspects of soluble-fibre inclusion in processed food products. Food Hydrocolloids, 25(2), 159-164. http://dx.doi.org/10.1016/j.foodhyd.2010.03.013

Li, M., Zhang, J. H., Zhu, K. X., Peng, W., Zhang, S. K., Wang, B., Zhu, Y. J., \& Zhou, H. M. (2012). Effect of superfine green tea powder on the thermodynamic, rheological and fresh noodle making properties of wheat flour. LWT-Food Science and Technology, 46(1), 23-28. http://dx.doi.org/10.1016/j.lwt.2011.11.005

Li, P. H., Huang, C. C., Yang, M. Y., \& Wang, C. C. R. (2012). Textural and sensory properties of salted noodles containing purple yam flour. Food Research International, 47(2), 223-228. http://dx.doi.org/10.1016/j.foodres.2011.06.035

Liu, L., Herald, T. J., Wang, D., Wilson, J. D., Bean, S. R., \& Aramouni, F. M. (2012). Characterization of sorghum grain and evaluation of sorghum flour in a Chinese egg noodle system. Journal of Cereal Science, 55(1), 31-36. http://dx.doi.org/10.1016/j.jcs.2011.09.007

Lutz, M., Martínez, A., \& Martínez, E. A. (2013). Daidzein and genistein contents in seeds of quinoa (Chenopodium quinoa Willd.) from local ecotypes grown in arid Chile. Industrial Crops and Products, 49, 117-121. http://dx.doi.org/10.1016/j.indcrop.2013.04.023

Manthey, F. A., Yalla, S. R., Dick, T. J., \& Badaruddin, M. (2004). Extrusion properties and cooking quality of spaghetti containing buckwheat bran flour. Cereal Chemistry, 81(2), 232-236. http://dx.doi.org/10.1094/CCHEM.2004.81.2.232 
Petitot, M., Boyer, L., Minier, C., \& Micard, V. (2010). Fortification of pasta with split pea and faba bean flours: Pasta processing and quality evaluation. Food Research International, 43(2), 634-641. http://dx.doi.org/10.1016/j.foodres.2009.07.020

Rayas-Duarte, P., Mock, C. M., \& Satterlee, L. D. (1996). Quality of spaghetti containing buckwheat, amaranth, and lupin flours. Cereal Chemistry, 73(3), 381-387.

Rosell, C. M., Rojas, J. A., \& Benedito de Barber, C. (2001). Influence of hydrocolloids on dough rheology and bread quality. Food Hydrocolloids, 15(1), 75-81. http://dx.doi.org/10.1016/S0268-005X(00)00054-0

Schlick, G., \& Bubenheim, D. L. (1996). Quinoa: Candidate crop for NASA's controlled ecological life support system. In J. Janick (Ed.), Progress in new crops (pp. 632-640). ASHS Press, Arlington, VA.

Silva, E., Birkenhake, M., Scholten, E., Sagis, L. M. C., \& van der Linden, E. (2013). Controlling rheology and structure of sweet potato starch noodles with high broccoli powder content by hydrocolloids. Food Hydrocolloids, 30(1), 42-52. http://dx.doi.org/10.1016/j.foodhyd.2012.05.002

Song, X., Zhu, W., Pei, Y., Ai, Z., \& Chen, J. (2013). Effects of wheat bran with different colors on the qualities of dry noodles. Journal of Cereal Science, 58(3), 400-407. http://dx.doi.org/10.1016/j.jcs.2013.08.005

Tan, H. Z., Li, Z. G., \& Tan, B. (2009). Starch noodle: History, classification, materials, processing, structure, nutrition, quality evaluation and improving. Food Research International, 42(5-6), 551-576. http://dx.doi.org/10.1016/j.foodres.2009.02.015

Tsai, P. J., Sheu, C. H., Wu, P. H., \& Sun, Y. F. (2010). Thermal and pH stability of betacyanin pigment of djulis (Chenopodium formosanum) in Taiwan and their relation to antioxidant activity. Journal of Agricultural and Food Chemistry, 58(2), 1020-1025. http://dx.doi.org/10.1021/jf9032766

Tsai, P. J., Chen, Y. S., Sheu, C. H., \& Chen, C. Y. (2011). Effect of nanogrinding on the pigment and bioactivity of djulis (Chenopodium formosanum Koidz.). Journal of Agricultural and Food Chemistry, 59(5), 1814-1820. http://dx.doi.org/10.1021/jf1041273

Zaidul, I. S. M., Karim, A. A., Manan, D. M. A., Ariffin, A., Norulaini, N. A. N., \& Omar, A. K. M. (2004). A farinograph study on the viscoelastic properties of sago/wheat flour dough. Journal of the Science of Food and Agriculture, 84(7), 616-622. http://dx.doi.org/10.1002/jsfa.1713

Zaidul, I. S. M., Yamauchi, H., Kim, S.-J., Hashimoto, N., \& Noda, T. (2007). RVA study of mixtures of wheat flour and potato starches with different phosphorus content. Food Chemistry, 102, 1105-1111. http://dx.doi.org/10.1016/j.foodchem.2006.06.056

\section{Copyrights}

Copyright for this article is retained by the author(s), with first publication rights granted to the journal.

This is an open-access article distributed under the terms and conditions of the Creative Commons Attribution license (http://creativecommons.org/licenses/by/3.0/). 